Short Communication

\title{
Preparation of Ni-W/PTFE Composite Coatings on Q345 Pipeline Steel and their Corrosion Resistance in Simulated Oilfield Produced Water
}

\author{
Yahong $\mathrm{Li}$ \\ College of Chemistry \& Chemical Engineering, Xi'an Shiyou University, \\ Xi'an 710065, China \\ E-mail: yhli_7100@163.com
}

Received: 2 December 2021 / Accepted: 17 January 2022 / Published: 2 February 2022

\begin{abstract}
Ni-W/PTFE composite coatings were prepared on the surface of Q345 pipeline steel by electrodeposition technology, and the effect of the concentration of PTFE particles added to the plating solution on the composition, surface morphology, surface roughness, and corrosion resistance in simulated oilfield produced water was investigated. The results show that with the increase of PTFE particles concentration from $2 \mathrm{~g} / \mathrm{L}$ to $12 \mathrm{~g} / \mathrm{L}$, the content of PTFE particles in the composite coating first increases and then decreases, while the crystal cell size and surface roughness first decrease and then increase, playing a big role on the corrosion resistance in simulated oilfield produced water. The Ni-W/PTFE composite coating prepared by adding $8 \mathrm{~g} / \mathrm{L}$ PTFE particles is compact and dense with only $0.372 \mu \mathrm{m}$ surface roughness, and the charge transfer resistance and coating resistance are about 2.4 times higher than that of Q345 pipeline steel. The Ni-W/PTFE composite coating has a protection efficiency of $70.6 \%$, which can significantly improve the corrosion resistance of Q345 pipeline steel in simulated oilfield produced water to prolong its service life.
\end{abstract}

Keywords: Q345 pipeline steel; Simulated oilfield produced water; Ni-W/PTFE composite coating; Corrosion resistance

\section{$\underline{\text { FULL TEXT }}$}

(C) 2022 The Authors. Published by ESG (www.electrochemsci.org). This article is an open access article distributed under the terms and conditions of the Creative Commons Attribution license (http://creativecommons.org/licenses/by/4.0/). 